\title{
Carcass properties, chemical content and fatty acid composition of the musculus longissimus of different pig genotypes
}

\author{
N. Parunovići ${ }^{\#}$, M. Petrović ${ }^{2}$, V. Matekalo-Sverak ${ }^{1}$, Č. Radović ${ }^{3}$ \& N. Stanišić ${ }^{3}$ \\ ${ }^{1}$ Institute of Meat Hygiene and Technology, 11000 Belgrade, Serbia \\ ${ }^{2}$ Institute of Animal Sciences, Faculty of Agriculture, University of Belgrade, 11040 Zemun, Serbia \\ ${ }^{3}$ Institute for Animal Husbandry, Belgrade, 11040 Zemun, Serbia
}

(Received 4 December 2012; Accepted 23 April 2013; First published online 26 May 2013)

\begin{abstract}
Copyright resides with the authors in terms of the Creative Commons Attribution 2.5 South African Licence.
See: http://creativecommons.org/licenses/by/2.5/za

Condition of use: The user may copy, distribute, transmit and adapt the work, but must recognise the authors and the South African Journal of Animal Science.
\end{abstract}

\begin{abstract}
The aim of this study was to examine carcass properties and variability in chemical content and fatty acid composition in the musculus longissimus lumborum et thoracis (MLLT) of different genotypes of pigs. Of 36 male castrated animals used in the trial, 24 were from two strains of Mangalitsa pigs (12 Swallow bellied (SBM) and 12 White (WM)), while 12 were of the Swedish Landrace (SL) breed (the most abundant meat/fattening breed in Serbia). The warm and cold carcass weights at slaughter were significantly higher in the WM and SL compared with the SBM. Results showed differences in warm and cold carcass dressing percentage between the groups. The SBM had significant lower values than WM and SL pigs. The total fat content was higher in WM and SBM pigs than SL pigs. The SL pigs had a significant higher percentage of water in their MLLT than the SBM and WM pigs. The representative of pig meat breeds, SL, contained significantly less cholesterol in its MLLT compared with the SBM and WM (-15.23\% and $-15.84 \%)$. However, differences in the content of saturated and unsaturated fatty acids were more expressed and distinct. A higher percentage of saturated fatty acids (SFA) and polyunsaturated fatty acids (PUFA) were present in MLTT originating from SL pigs compared with the two Mangalitsa strains. The total monounsaturated fatty acids (MUFA) content was higher in SBM and WM than in SL pigs. The alpha linolenic acid concentration (C18:3 n-3) was significantly higher in SBM than in WM and SL pigs.
\end{abstract}

Keywords: Mangalitsa, carcass traits, meat quality, cholesterol, fatty acids, Swedish Landrace

\#Corresponding author: nenad@inmesbgd.com

\section{Introduction}

The Mangalitsa is an indigenous swine breed and was the most typical breed in Serbia over 100 years ago. The breeders created a very robust and resistant race. The blond Mangalitsa proved to be the most popular, but also other colour variants, such as black, red and brownish-grey (wolf). The Swallow-bellied and the wild type (baris) were also found. However, in the middle of the last century, the population decreased and nearly disappeared because of the breed's excessive lard and lower reproductive performance than modern commercial breeds. In recent years, zoologists and livestock breeders worldwide have joined forces in the interests of saving indigenous breeds from extinction and introduced domestic livestock breeds. The best strategy for preventing the disappearance of such breeds is to strive to maintain genetic diversity, in which the indigenous breeds can prove useful.

The future of the Mangalitsa is dependent largely on whether products derived from it can be utilized effectively, and whether long-term market opportunities can be secured. The Mangalitsa pig is currently enjoying a renaissance, owing to endeavours aimed at restoring the presence of traditional breeds. Its meat is of outstanding quality; it has a high dry matter content, and its red colour corresponds to current 
requirements. The distinct palatable flavour is derived from the fat surrounding the muscle tissue (Csapó et al., 2002).

Mangalitsa is a typical representative of the fatty pig breeds. That is, its average total mass consists of 65\% - 70\% fat tissue and 30\% - 35\% meat (Egerszegi et al., 2003). Today, apart from the gene preservation aspect, rearing Mangalitsa pigs is commercialized by processing the high-quality meat into products that are attracting increasing interest in the food manufacturing market. The results of recent research (Szabó, 2001; Szabó, 2002) show that less than $40 \%$ of a Mangalitsa specimen consists of lean meat, which is reason enough for production of its high-quality and tasty products.

Mangalitsa meat belongs to the group of fat rich meat. Its fresh meat is darker, more succulent and softer than the meat from other pig breeds. Its odour is stronger. The tenderness of Mangalitsa pork is much higher than that obtained from any other commercial pig breed (Flegler, 1999).

Some findings were published recently in connection with the fatty acid composition and cholesterol content of the meat and backfat of the Mangalitsa pig. It was claimed that the fat is softer and easier to digest by human beings than that of modern pigs. Its softer, granular consistency is attributable to its different and also 'healthier' fatty acid composition. Another view is that the cholesterol content of the fat is substantially lower than that of the new, intensively fed genotypes of pigs (Csapó et al., 2002).

The fatty acid composition of foodstuffs is of great importance to healthy human nutrition. Pork contains high quantities of saturated fatty acids (SFA) and cholesterol. An excessive intake of these components through meat consumption may lead to arteriosclerosis-related illnesses (Grys, 1995). Nutritionists recommend a reduction in total fat intake, particularly of SFA and trans fatty acids, which are associated with an increased risk of cardio-vascular diseases and some cancers (Burlingame et al., 2009; Brouwer et al., 2010; USDA \& HHS, 2010; Mapiye et al., 2011). Besides reducing fat intake, nutritionists urge consumers to increase their intake of polyunsaturated fatty acids (PUFA), particularly the $n$-3 PUFA, at the expense of n-6 PUFA (Simopoulos, 2004; Griffin, 2008; Harris et al., 2009; Mapiye et al., 2011). Therefore, PUFA/SFA and $n$-6/n-3 PUFA ratios have become important parameters in evaluating the nutritional value and healthiness of foods (Aldai et al., 2005; Alfaia et al., 2007; Riediger et al., 2009; Mapiye et al., 2011). Nevertheless, in recent years, red meat consumption has been discredited because of causal relations established between red meat consumption and coronary heart disease (CHD) and cancer (Forman, 1999).

Hungarian researchers studied the fatty acid and cholesterol content of fatty tissues in Mangalitsa and Mangalitsa crosses with other breeds. They established that the unsaturated fatty acid content was greater than $60 \%$ in the Mangalitsa pig fat and reached almost the same percentage in the crosses (Csapó et al., 1999; Csabó, 2001). Differences in cholesterol content detected in various breeds were insignificant (Csapó et al., 1999). In addition, $68.7 \%$ of intramuscular fat in the musculus longissimus dorsi consists of unsaturated fatty acids, which represents a 6\% increase in comparison with the German Landrace breed (Ender et al., 2002).

The Swedish Landrace (SL) is one of the most common genotypes of pigs in Serbia and was thus selected for the current investigation.

The objective of this study was to investigate carcass traits and differences in chemical content and fatty acid composition, as well as cholesterol content in musculus longissimus lumborum et thoracis (MLLT) of different genotypes of pigs.

\section{Material and Methods}

Of 36 male castrated animals used in the trial, 24 (12 x 2) were Mangalitsa pigs (Swallow-bellied (SBM) and White (WM)), while 12 were of the SL breed. The experimental pigs were reared in late spring and early summer. Animals were kept in their natural habitat within the same area, on a small farm near the

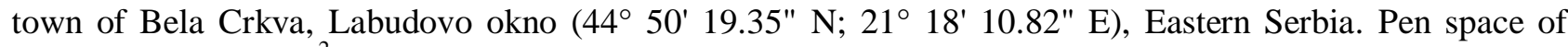
approximately $10 \mathrm{~m}^{2}$ was allocated to each animal. The pigs were fed twice a day in troughs with simultaneous access for all. When the experimental pigs reached between $20 \mathrm{~kg}$ and $25 \mathrm{~kg}$ in weight, all were housed in the same indoor area, with six pigs to a cage and $5 \mathrm{~m}^{2}$ ground area per animal. The pens formed part of a group located inside a commercial pig grower's shed. This shed was enclosed with walls and had a roof. Manually opening and closing windows controlled airflow. The floor of the pen was made of concrete. One third of the pens had concrete slats above the faeces and urine drainage channel. Throughout the 
investigation, the Mangalitsa and SL pigs were fed ad libitum diets of identical composition from selffeeders. The feed composition and analysed nutrients are presented in Table 1.

At the end of the trial, pigs were transported in the morning (between 8:00 and 9:00) to the nearby commercial abattoir of Banatski Karlovac (approximately $40 \mathrm{~km}$ ) in groups of a maximum of 12 animals. They were all transported in a trailer by the same person. The time between arrival in the abattoir and the onset of slaughtering varied between $20 \mathrm{~h}$ and $22 \mathrm{~h}$. This was performed by the same people over the slaughter days.

Table 1 Ingredient composition (\% as-fed) and estimated analyses (g/kg) of the diet

\begin{tabular}{lcc}
\hline \multirow{2}{*}{ Ingredients } & \multicolumn{2}{c}{ Body weight (kg) } \\
\cline { 2 - 3 } & $25-60$ & $60-100$ \\
\hline Maize & 62.9 & 68.8 \\
Wheat feed flour & 15.0 & 15.0 \\
Soy press cake & 14.0 & 9.1 \\
Sunflower press cake & 5.0 & 4.0 \\
Calcium carbonate & 1.4 & 1.4 \\
Monocalcium phosphate & 0.6 & 0.7 \\
Sodium chloride & 0.40 & 0.45 \\
Vitamin and micromineral premix & 0.5 & 0.5 \\
Lysine & 0.07 & 0.09 \\
Minazel plus (Min-a-Zel Plus) & 0.10 & - \\
Total & 100 & 100 \\
Estimated nutrient content & & \\
$\quad$ Crude protein (N x 6.25) & 15.00 & 13.00 \\
$\quad$ Crude fat & 3.48 & 3.62 \\
$\quad$ Crude dietary fibre & 4.21 & 3.87 \\
Crude ash & 5.01 & 4.88 \\
$\quad$ ME content, MJ/kg & 12.95 & 13.05 \\
\hline
\end{tabular}

The animals were slaughtered at similar live weights (100 kg), but not similar ages, because slaughter and transport procedures could be standardized, but differences in carcass weight would have overruled other effects on carcass conformation or meat quality.

Before slaughtering, feed was withdrawn overnight. The animals were conventionally slaughtered according to standard commercial procedures after electrical stunning (250 V AC, ear to ear for 3-5 s) and sticking within $30 \mathrm{~s}$. Thereafter the pigs were eviscerated and inspected by the appropriate government health official. This was performed by the same people. The body weight of the trial pigs was measured prior to and shortly after slaughter. Carcasses contained heads, trotters and kidney fat. Each carcass was weighed warm and then chilled $\left(4{ }^{\circ} \mathrm{C}\right.$ for $\left.24 \mathrm{~h}\right)$. At 45 minutes post mortem, the initial $\mathrm{pH}$ was taken $\left(\mathrm{pH}_{45}\right)$. After the $24 \mathrm{~h}$ chilling period the final $\mathrm{pH}\left(\mathrm{pH}_{24}\right)$ was measured. The $\mathrm{pH}$ measurements were taken on the MLLT. The $\mathrm{pH}$ was measured with a penetrating glass electrode on a hand-held Testo $205 \mathrm{pH}\left( \pm 0.02 \mathrm{pH} ; \pm 0.4{ }^{\circ} \mathrm{C}\right.$; Germany, 2007). The $\mathrm{pH}$ meter was rinsed with distilled water after every reading and re-calibrated after every fourth reading. During routine carcass splitting and cutting, samples of the MLLT were taken between the 13th and 14th thoracic vertebra and stored in a freezer for further analyses. Prior to laboratory analysis, all the samples were vacuum-packed and kept frozen at approximately $-20{ }^{\circ} \mathrm{C}$.

The chemical composition of the MLLTs was measured, viz. protein, water, total fats, ash, fatty acids and cholesterol contents, using the methods as defined by the AOAC (1990). Cholesterol concentration was 
determined by HPLC/PDA, on a HPLC Waters 2695 separation module, with a Waters 2996 photodiode array detector, as described by Maraschiello et al. (1996). Chromatographic separation was achieved with a Phenomenex Luna $\mathrm{C}_{18(2)}$ column $(150 \mathrm{~mm} \times 3.0 \mathrm{~mm}, 5 \mu \mathrm{m})$ with adequate pre-column, isocratically, with mobile phase of isopropanol-acetonitrile 20\%:80\% v/v. Injection volume was $10 \mu \mathrm{L}$. Cholesterol was determined by absorption at a wavelength of $210 \mathrm{~nm}$. Analytical yield (recovery) for given quantities was between $66.3 \%$ and $74.8 \%$. External calibration was used to calculate the cholesterol content. Empower Pro software was employed for system control and data gathering and processing.

In order to determine the concentration of fatty acids, total lipids were extracted by a rapid extraction method, using solvents on the Dionex ASE 200. A homogenized sample, mixed with diatomaceous earth, was extracted with a mixture of hexane and isopropanol $(60: 40 \mathrm{v} / \mathrm{v})$ in a $33 \mathrm{~mL}$ extraction cell at $100^{\circ} \mathrm{C}$ and under nitrogen pressure of $10.3 \mathrm{MPa}$. The extract thus obtained was steamed in a nitrogen flow at $50{ }^{\circ} \mathrm{C}$ until dry fat remains were obtained (Spirić et al., 2010).

Fatty acids as methyl esters were detected by capillary gas chromatography with a flame ionization detector. A predetermined quantity of lipid extracts, obtained by the rapid extraction method, was dissolved in tert-butyl methyl ether. Fatty acids were converted to fatty acids methyl esters (FAME) with trimethylsulfonium hydroxide, according to the SRPS EN ISO 5509:2007 method. FAMEs were analysed with a GC-FID Shimadzu 2010 device (Kyoto, Japan) on a cyanopropyl-aryl column HP-88 (column length 100 , internal diameter $0.25 \mathrm{~mm}$, film thickness $0.20 \mu \mathrm{m}$ ). The injected volume was $1 \mu \mathrm{L}$. Temperatures of the injector and detector were $250{ }^{\circ} \mathrm{C}$ and $280{ }^{\circ} \mathrm{C}$, respectively. Nitrogen was used as a carrier gas, 1.33 $\mathrm{mL} / \mathrm{min}$, with a split ratio of $1: 50$, while hydrogen and air were used as detector gases. The temperature of the column furnace was programmed to range between $120^{\circ} \mathrm{C}$ and $230{ }^{\circ} \mathrm{C}$. The total duration of analysis was $50.5 \mathrm{~min}$. Methyl esters of acids were identified according to their retention times, which were compared with those of the mixture of methyl esters of fatty acids in the standard Supelco 37 Component FAME mix (Spirić et al., 2010).

The experimental data were statistically processed and analysed by the least squares method and by applying the GLM procedure of the SAS 9.1.3 program package (SAS Inst. Inc. 2002-2003). The breed was introduced into the model as an independent variable, while the mass of freshly slaughtered pig carcass sides was a dependent variable. When means were significantly different, Tukey's test was applied to compare the mean values of the genotypes. The data in the tables are presented as least squares means (LSM) and standard errors of the mean (SEM).

\section{Results and Discussion}

The results for the final live weight and carcass characteristics are presented in Table 2 . When the trial ended, there were no significant differences $(P>0.05)$ in live weight gain between the groups, as mean final live weights were similar in the three experimental groups, at about $100 \mathrm{~kg}$. Significant differences were observed between the carcass weights of the experimental groups. The warm and cold carcass weights at slaughter were higher $(P<0.01)$ in the WM and SL than the SBM group. However, final live weight had a significant $(P<0.01)$ influence on the warm and cold carcass weight of pigs. In a similar study, Petrović et al. (2010) found significant differences in average masses of carcass sides (warm and cooled carcass sides) between breeds. The average mass of the cooled carcass sides of Moravka pigs was higher $(84.2 \mathrm{~kg})$ than SBM pigs $(73.9 \mathrm{~kg})$. In Table 2, the current results showed noticeable differences in warm and cold carcass dressing percentage between the groups. The SBM had significantly lower values than WM and SL ( $P$ $<0.01)$. However, the final live weight had a significant influence $(P<0.01)$ on carcass dressing percentage. Hoffman et al. (2003), in their study, presented the results of warm $(77.5 \%$ - 77.7\%) and cold (75.9\% 76.4\%) dressing percentages of pig carcasses. Neither warm, nor cold dressing percentages differed significantly between the groups. In our study, a significant $(P<0.01)$ difference in cooler shrink was observed between the pig genotypes. The SL pigs underwent less cooler shrink $(1.80 \%)$ than the other two groups. Anupam et al. (2010) examined the slaughter performance of Ghungroo, a native swine breed, and found that they produced cooler shrink values ranging from $1.90 \%$ to $5.48 \%$.

The average $\mathrm{pH}_{45}$ and $\mathrm{pH}_{24}$ values in $M L L T$ were different $(P<0.01)$ depending on pig genotype (Table 2). Initial muscle $\mathrm{pH}$ in SBM pigs had lower values than $\mathrm{WM}$ and SL $(P<0.01)$. The final $\mathrm{pH}$ measurements showed that SBM pigs had lower $(P<0.001) \mathrm{pH}$ values compared with WM and SL pigs. In a similar study, Parunović et al. (2012a) concluded that the differences in the average $\mathrm{pH}$ values of $M L L T$ were statistically significant between SL and WM (5.45 and 5.61; $P \leq 0.05$ ), and between SBM and WM (5.42 and 
5.61; $P \leq 0.05)$. Hoffman et al. (2003) concluded that muscle $\mathrm{pH}$ values $\left(\mathrm{pH}_{45}\right.$ and $\left.\mathrm{pH}_{24}\right)$ were not influenced by the two housing systems, free-range and conventional. Sather et al. (1997) found that initial muscle $\mathrm{pH}$ of free-range pigs tended to be lower than that of conventionally housed pigs. The results of Barton Gade \& Blaabjerg (1989) and Enfält et al. (1997) showed that free-range pigs had lower final pH measurements than indoor housed pigs. Parunović et al. (2012b) reported that the initial muscle $\mathrm{pH}$ in the free-range Mangalitsa pigs had lower values than those of conventionally reared ones $(P<0.01)$. The final $\mathrm{pH}$ measurements showed that the free-range pigs had lower $(P<0.001) \mathrm{pH}$ values than pigs reared indoors. These researchers reasoned that free-range pigs had higher levels of muscle glycogen than their pen-housed counterparts, which resulted in lower $\mathrm{pH}$ readings. Since our experimental pigs were kept in the same conditions, the initial and final muscle $\mathrm{pH}$ values clearly differed depending on the genotype of pigs.

Table 2 Comparison of least squares means \pm (SEM) for slaughter traits and levels of significance difference between pig genotypes

\begin{tabular}{lccccc}
\hline \multirow{2}{*}{ Trait } & $\begin{array}{c}\text { Swallow-bellied } \\
\text { Mangalitsa SBM }\end{array}$ & $\begin{array}{c}\text { White Mangalitsa } \\
\text { WM }\end{array}$ & $\begin{array}{c}\text { Swedish Landrace } \\
\text { SL }\end{array}$ & \multicolumn{2}{c}{$\begin{array}{c}\text { Significance } \\
\text { of the influence }\end{array}$} \\
\cline { 2 - 6 } & $(\mathrm{n}=12)$ & $(\mathrm{n}=12)$ & $(\mathrm{n}=12)$ & Genotype & LW \\
\hline Live weight (kg) & $100.7 \pm 3.62$ & $100.8 \pm 3.62$ & $96.2 \pm 5.36$ & $/$ & $/$ \\
Warm carcass weight (kg) & $76.2^{\mathrm{b}} \pm 0.56$ & $78.5^{\mathrm{a}} \pm 0.56$ & $79.1^{\mathrm{a}} \pm 0.59$ & $* *$ & $* * *$ \\
Cold carcass weight (kg) & $74.3^{\mathrm{b}} \pm 0.61$ & $76.5^{\mathrm{a}} \pm 0.61$ & $77.7^{\mathrm{a}} \pm 0.65$ & $* *$ & $* * *$ \\
Warm carcass DP (\%) & $76.4^{\mathrm{b}} \pm 0.59$ & $78.9^{\mathrm{a}} \pm 0.59$ & $79.6^{\mathrm{a}} \pm 0.62$ & $* *$ & $* *$ \\
Cold carcass (\%) & $74.4^{\mathrm{b}} \pm 0.63$ & $76.8^{\mathrm{a}} \pm 0.63$ & $78.1^{\mathrm{a}} \pm 0.67$ & $* *$ & $* *$ \\
Cooler shrink (\%) & $2.52^{\mathrm{b}} \pm 0.18$ & $2.63^{\mathrm{b}} \pm 0.18$ & $1.80^{\mathrm{a}} \pm 0.19$ & $* *$ & NS \\
$\mathrm{pH}^{45}$ MLLT & $5.96^{\mathrm{b}} \pm 0.06$ & $6.06^{\mathrm{b}} \pm 0.06$ & $6.41^{\mathrm{a}} \pm 0.09$ & $* *$ & NS \\
$\mathrm{pH}^{24}$ MLLT & $5.58^{\mathrm{c}} \pm 0.05$ & $5.77^{\mathrm{b}} \pm 0.05$ & $6.00^{\mathrm{a}} \pm 0.07$ & $* * *$ & NS
\end{tabular}

LW: live weight; MLLT: musculus longissimus lumborum et thoracis; n: number of samples; DP: dressing percentage; NS: not significant $(P \geq 0.05)$.

"Statistical significance at the level of $P<0.05$; ** Statistical significance at the level of $P<0.01$;

${ }_{* * * *}^{*}$ Statistical significance at the level of $P<0.001$.

${ }^{\mathrm{a}-\mathrm{c}}$ Means within a row with different superscripts differ $(P<0.05)$.

Comparisons of the means of the chemical composition of the MLLT derived from the various pig genotypes are presented in Table 3. Significant differences were found in chemical content of the MLLT between the groups. SL MLLT contained a higher $(P<0.001)$ percentage of water than the $M L L T$ in the other two groups of pigs. The difference in water content between SBM and WM was not significant. However, final live weight had a significant influence on water content in $M L L T(P<0.01)$. The established value of water content in SL pigs (72.7\%) was similar to the value of $71.9 \%$ found by Rahelic (1984), the $72.3 \%$ to 73.8\% found by Estévez, et al. (2003) for Iberian pigs and Landrace pigs, but slightly below the average value of 75.5\% obtained by Kim et al. (2008) for SL pigs. Holló et al. (2003) found water content ranged between $68.8 \%$ and $69.0 \%$ in Mangalitsa pigs of different body masses.

The differences in mean protein values between the groups were significant $(P<0.01)$ (Table 3$)$. In our research, WM pigs had a lower protein content in MLLT compared with the results obtained by Holló et al. (2003) and Petrović et al. (2009). In the current study, the protein content of WM (19.5\%) was lower than the $21.16 \%$ of SBM and $22.1 \%$ of SL, which were lower than those presented by Rahelic (1984). In the current study, the differences in protein content between SL (22.1\%) and the two Mangalitsa strains (21.2\% and 19.5\%) were lower than those presented by Rahelić (1984). Values of protein content in the MLTT of pigs, according to data verified by other authors, vary from $21.2 \%$ to $24.1 \%$ (Rahelić, 1984; Holló et al., 2003; Jacyno et al., 2006; Kim et al., 2008). Rearing pigs of the same genotype (Italian local breed) in an open system, instead of closed, while providing them with a diet based on commercial mixtures, increased their intramuscular and intermuscular fat and protein content (23.5\% to 22.8\%) (Pugliese et al., 2005). The 
protein content in MLTT of both Mangalitsa and SL pigs, as calculated in our research, was lower than that reported by Rey et al. (2004) and Pugliese et al. (2005).

Total fat content in the MLLT was higher in WM and SBM pigs than in SL pigs, and these differences were significant $(P<0.001)$. However, final live weight had a significant $(P<0.05)$ influence on total fat content in MLLT. Rahelić (1984), Holló et al. (2003) and Petrović et al. (2009) established that MLLT from Mangalitsa pigs contained between $4.91 \%$ and $9.04 \%$ of pure fat. Our research determined that total fat content in MLLT from Mangalitsa pigs was between $13.5 \%$ and $16.8 \%$, which was higher than in previous studies.

The statistical difference in ash content between the groups was found to be significant $(P<0.01)$. Ash content in MLLT of WM and SBM pigs was lower than in that of SL pigs. There was no difference in the ash content of MLLT derived from the two types of Mangalitsa pigs. Rahelić (1984) spotted a slight difference in ash content between Mangalitsa and Swedish Landrace (1.21\% and 1.18\%), while Holló et al. (2003) established no significant difference in average ash content in $M L L T$ in three trial groups of Mangalitsa pigs.

Table 3 Comparison of least squares means \pm (SEM) for the chemical composition of musculus longissimus lumborum et thoracis traits (\%) and levels of significance difference

\begin{tabular}{|c|c|c|c|c|c|}
\hline \multirow{2}{*}{ Trait } & \multirow{2}{*}{$\begin{array}{c}\text { Swallow-bellied } \\
\text { Mangalitsa SBM } \\
(\mathrm{n}=12)\end{array}$} & \multirow{2}{*}{$\begin{array}{c}\text { White Mangalitsa } \\
\text { WM } \\
(\mathrm{n}=12)\end{array}$} & \multirow{2}{*}{$\begin{array}{c}\text { Swedish Landrace } \\
\text { SL } \\
(\mathrm{n}=12)\end{array}$} & \multicolumn{2}{|c|}{$\begin{array}{l}\text { Significance of the } \\
\text { influence }\end{array}$} \\
\hline & & & & Genotype & LW \\
\hline Water (\%) & $64.3^{\mathrm{b}} \pm 1.17$ & $62.7^{\mathrm{b}} \pm 1.17$ & $72.7^{\mathrm{a}} \pm 1.23$ & $* * *$ & $* *$ \\
\hline Protein (\%) & $21.1^{\mathrm{a}} \pm 0.60$ & $19.5^{b} \pm 0.60$ & $22.1^{\mathrm{a}} \pm 0.64$ & $* *$ & NS \\
\hline Fat (\%) & $13.5^{\mathrm{b}} \pm 1.71$ & $16.8^{\mathrm{b}} \pm 1.72$ & $4.23^{\mathrm{a}} \pm 1.82$ & $* * *$ & $*$ \\
\hline Ash (\%) & $0.95^{\mathrm{b}} \pm 0.03$ & $0.89^{b} \pm 0.03$ & $1.06^{\mathrm{a}} \pm 0.03$ & $* * *$ & NS \\
\hline Fat : protein ratio ${ }^{1}$ & $0.68^{\mathrm{b}} \pm 0.10$ & $0.91^{\mathrm{b}} \pm 0.10$ & $0.20^{\mathrm{a}} \pm 0.11$ & $* * *$ & $*$ \\
\hline
\end{tabular}

LW: live weight; $\mathrm{n}=$ number of samples; NS: not significant $(P \geq 0.05)$.

*Statistical significance at the level of $\mathrm{P}<0.05 ;{ }^{* *}$ Statistical significance at the level of $P<0.01$;

${ }^{* * *}$ Statistical significance at the level of $P<0.001$.

${ }^{1} \mathrm{Fat} /$ protein ratio was calculated.

${ }^{\mathrm{a}-\mathrm{c}}$ Means within a row with different superscripts differ $(P<0.05)$.

The calculated fat/protein ratio was significantly lower in $M L L T$ of the SL pigs compared with both genotypes of Mangalitsa pigs, and these differences were significant $(P<0.001)$. However, final live weight also had a significant $(P<0.05)$ influence on fat/protein ratio in $M L L T$.

The fatty acid composition and cholesterol concentration of MLLT from the examined pigs are shown in Table 4. In general, palmitic acid (C16:0) was the most abundant SFA, with average percentages between 23.3 and 24.3, oleic acid (C18:1 cis-9) the most abundant monounsaturated fatty acids (MUFA) (between $38.6 \%$ and $47.3 \%$ ), and linoleic acid (C18:2 $n-6)$ the most abundant PUFA (between $4.06 \%$ and $8.76 \%$ ) in the $M L L T$ of the examined pigs. The SFA and PUFA concentrations were found in higher $(P<0.001)$ percentages in MLLT of SL pigs (43.4\% and 11.5\%, respectively) than in the SBM and WM pigs. In contrast, MUFA and unsaturated fatty acid (USFA) were found in higher $(P<0.001)$ percentages in the MLLT of SBM and WM than in SL pigs. Zăhan et al. (2010) showed Mangalitsa pigs contained high levels of palmitic and stearic (SFA), oleic (MUFA) and linoleic (PUFA) fatty acids. The amount of linoleic acid they found was double that found for the same pig breed by other researchers (Holló et al., 2003). The results of research by Sans et al. (2004) on fresh meat quality in Gascon pigs that were reared within an open system connected to natural resources and fed acorns and limited quantities of concentrates showed more MUFA (58.3\%), and less SFA (36.1\%) and PUFA (5.61\%) in musculus longissimus dorsi. Furthermore, some statistically significant differences in their fatty acid content were noted, depending on the type of muscle examined (musculus longissimus dorsi and musculus biceps femoris). Similar values for MUFA concentration (58.1\%) in musculus longissimus dorsi (MLD) of Iberian pigs reared in an open system were established by Rey et al. 
(2004). In our study, MUFA content in Mangalitsa animals (SBM and WM), especially in the WM breed (58.0\% MUFA), confirmed the results of other authors. The Duroc breed is known for its high intramuscular fat content relative to backfat content compared with other breeds. In line with these considerations, the intramuscular SFA and MUFA proportions were higher and the PUFA proportions were lower for Duroc than for British Landrace pigs (De Smet et al., 2004). Cameron et al. (2000) studied the genotype by nutrition interactions on fatty acid composition of intramuscular fat in Large White pigs. There were selection line effects on the fat content and on the fatty acid composition of triacylglycerols and phospholipids, but the diet effects were larger than the selection line effects, especially on the $n-6 / n-3$ ratio. More importantly, there was no evidence of genotype-nutrition interactions.

Table 4 Comparison of least squares means \pm (SEM) for fatty acid composition (\%) and cholesterol concentration (mg/100 g) of musculus longissimus lumborum et thoracis traits and level of significance differences

\begin{tabular}{|c|c|c|c|c|c|}
\hline \multirow[t]{2}{*}{ Trait } & \multirow{2}{*}{$\begin{array}{c}\text { Swallow-bellied } \\
\text { Mangalitsa (SBM) } \\
(\mathrm{n}=12)\end{array}$} & \multirow{2}{*}{$\begin{array}{l}\text { White Mangalitsa } \\
\text { (WM) } \\
(\mathrm{n}=12)\end{array}$} & \multirow{2}{*}{$\begin{array}{c}\text { Swedish Landrace } \\
\text { (SL) } \\
(\mathrm{n}=12)\end{array}$} & \multicolumn{2}{|c|}{$\begin{array}{l}\text { Significance of the } \\
\text { influence }\end{array}$} \\
\hline & & & & Genotype & LW \\
\hline C14:0 & $1.22^{\mathrm{a}} \pm 0.03$ & $1.13^{\mathrm{a}} \pm 0.03$ & $1.13^{\mathrm{a}} \pm 0.04$ & NS & NS \\
\hline C16:0 & $24.3^{\mathrm{a}} \pm 0.46$ & $23.3^{\mathrm{a}} \pm 0.46$ & $24.3^{\mathrm{a}} \pm 0.49$ & NS & NS \\
\hline C17:0 & $0.24^{\mathrm{c}} \pm 0.02$ & $0.19^{\mathrm{b}} \pm 0.02$ & $0.12^{\mathrm{a}} \pm 0.03$ & $* *$ & NS \\
\hline C18:0 & $9.30^{\mathrm{b}} \pm 0.32$ & $9.01^{b} \pm 0.32$ & $12.94^{\mathrm{a}} \pm 0.34$ & $* * *$ & NS \\
\hline C20:0 & $0.14^{\mathrm{b}} \pm 0.01$ & $0.12^{\mathrm{b}} \pm 0.01$ & $0.20^{\mathrm{a}} \pm 0.01$ & $* * *$ & NS \\
\hline C16:1 & $4.62^{\mathrm{b}} \pm 0.19$ & $4.21^{\mathrm{b}} \pm 0.19$ & $2.27^{\mathrm{a}} \pm 0.20$ & $* * *$ & NS \\
\hline C17:1 & $0.24^{\mathrm{C}} \pm 0.01$ & $0.21^{\mathrm{b}} \pm 0.01$ & $\mathrm{ND}^{\mathrm{a}}$ & $* * *$ & $* * *$ \\
\hline C18:1 cis-9 & $44.2^{\mathrm{C}} \pm 0.88$ & $47.3^{\mathrm{b}} \pm 0.88$ & $38.6^{a} \pm 0.93$ & $* * *$ & NS \\
\hline C18:1 trans-9 & $0.56^{\mathrm{b}} \pm 0.03$ & $0.53^{\mathrm{b}} \pm 0.03$ & $\mathrm{ND}^{\mathrm{a}}$ & $* * *$ & NS \\
\hline C18:1 cis-11 & $4.71^{b} \pm 0.16$ & $5.03^{\mathrm{b}} \pm 0.16$ & $3.34^{\mathrm{a}} \pm 0.17$ & $* * *$ & NS \\
\hline C18:2 n-6 & $5.43^{\mathrm{b}} \pm 0.51$ & $4.06^{\mathrm{b}} \pm 0.51$ & $8.76^{\mathrm{a}} \pm 0.54$ & $* * *$ & NS \\
\hline C18:3n-3 & $0.48^{\mathrm{a}} \pm 0.04$ & $0.18^{\mathrm{b}} \pm 0.04$ & $0.20^{\mathrm{a}} \pm 0.05$ & $* * *$ & NS \\
\hline C20:1 n-9 & $0.75 \pm 0.02$ & $0.71 \pm 0.02$ & $0.70 \pm 0.02$ & NS & NS \\
\hline C20:2 n-6 & $0.34^{\mathrm{b}} \pm 0.03$ & $0.28^{\mathrm{b}} \pm 0.03$ & $0.45^{\mathrm{a}} \pm 0.03$ & $* * *$ & NS \\
\hline C20:3 $n-3$ & $\mathrm{ND}^{\mathrm{b}}$ & $\mathrm{ND}^{\mathrm{b}}$ & $0.96^{\mathrm{a}} \pm 0.17$ & $* * *$ & NS \\
\hline C20:3 n-6 & $0.46 \pm 0.04$ & $0.46 \pm 0.04$ & $0.43 \pm 0.05$ & NS & NS \\
\hline C22:1 + C 20:4 & $0.21^{\mathrm{b}} \pm 0.19$ & $0.22^{\mathrm{b}} \pm 0.19$ & $1.19^{\mathrm{a}} \pm 0.20$ & $* * *$ & NS \\
\hline $\mathrm{C} 22: 5 n-3$ & $0.09^{\mathrm{b}} \pm 0.01$ & $0.01^{\mathrm{a}} \pm 0.01$ & $\mathrm{ND}^{\mathrm{a}}$ & $* * *$ & $*$ \\
\hline SFA & $35.3^{\mathrm{b}} \pm 0.53$ & $33.8^{\mathrm{b}} \pm 0.53$ & $43.4^{\mathrm{a}} \pm 0.56$ & $* * *$ & NS \\
\hline MUFA & $55.1^{\mathrm{b}} \pm 1.04$ & $58.0^{\mathrm{b}} \pm 1.05$ & $44.9^{\mathrm{a}} \pm 1.11$ & $* * *$ & NS \\
\hline PUFA & $7.01^{b} \pm 0.77$ & $5.21^{b} \pm 0.77$ & $11.47^{\mathrm{a}} \pm 0.81$ & $* * *$ & NS \\
\hline USFA & $62.1^{b} \pm 0.45$ & $63.2^{\mathrm{b}} \pm 0.45$ & $56.3^{\mathrm{a}} \pm 0.48$ & $* * *$ & NS \\
\hline Total $n-3$ PUFA & $0.57^{\mathrm{b}} \pm 0.05$ & $0.19^{\mathrm{a}} \pm 0.05$ & $0.20^{\mathrm{a}} \pm 0.05$ & $* * *$ & NS \\
\hline Total $n-6$ PUFA & $6.23^{\mathrm{a}} \pm 0.51$ & $4.80^{\mathrm{a}} \pm 0.51$ & $9.63^{b} \pm 0.54$ & $* * *$ & NS \\
\hline MUFA/PUFA & $8.32^{\mathrm{C}} \pm 0.60$ & $11.45^{\mathrm{b}} \pm 0.60$ & $4.51^{\mathrm{a}} \pm 0.64$ & $* * *$ & NS \\
\hline MUFA/SFA & $1.56^{\mathrm{c}} \pm 0.04$ & $1.72^{\mathrm{b}} \pm 0.04$ & $1.04^{\mathrm{a}} \pm 0.04$ & $* * *$ & NS \\
\hline PUFA/SFA & $0.20^{\mathrm{b}} \pm 0.01$ & $0.15^{\mathrm{b}} \pm 0.01$ & $0.33^{\mathrm{a}} \pm 0.02$ & *** & NS \\
\hline$n-6 / n-3$ PUFA & $14.05^{\mathrm{b}} \pm 2.99$ & $34.01^{\mathrm{a}} \pm 2.99$ & $45.63^{\mathrm{a}} \pm 3.17$ & $* * *$ & NS \\
\hline Cholesterol & $62.3^{\mathrm{b}} \pm 1.97$ & $62.9^{\mathrm{b}} \pm 1.97$ & $47.1^{\mathrm{a}} \pm 2.09$ & $* * *$ & NS \\
\hline
\end{tabular}

LW: live weight; n: number of samples; ND: not detected; NS: not significant $(P \geq 0.05)$; ${ }^{*}$ Statistical significance at the level of $P<0.05$; ${ }^{* *}$ Statistical significance at the level of $P<0.01$; ${ }^{* * *}$ Statistical significance at the level of $P<0.001$. SFA: saturated fatty acids; MUFA: monounsaturated fatty acids; PUFA: polyunsaturated fatty acids.

USFA: monounsaturated fatty acids + polyunsaturated fatty acids; content of SFA, MUFA, PUFA - calculated from all detected acids. ${ }^{\mathrm{a}-\mathrm{c}}$ Means within a row with different superscripts differ $(P<0.05)$. 
In the current study, Mangalitsa pigs showed higher levels of MUFA $(P<0.001)$ in the $M L L T$ than SL pigs. Ruiz et al. (1998) and Andrés et al. (2001) concluded that free-reared pigs fed on pasture and acorns showed higher levels of MUFA than those fed on concentrates. Nevertheless, in our study, oleic acid (C18:1 cis-9) levels in MLLT of Mangalitsa pigs were considerably higher than average levels of this fatty acid in the meat of SL pigs. These results are consistent with research from Hansen et al. (2006), demonstrating that organically reared pigs had a higher content of PUFA and a lower content of MUFA. Similarly, there were higher levels of C18:2 $n-6$ and PUFA $n-6$ in pigs fed organically than in pigs fed conventionally (Högberg et al., 2003). In our research, the higher C18:2 n-6 concentration in SL pigs contributed to the higher total PUFA concentration in SL pigs (11.47 \pm 0.81$)$ compared with Mangalitsa pigs. This finding is consistent with the results of Nilzén et al. (2001). The higher level of this fatty acid in the SL pigs resulted in these animals having a higher overall amount of $n-6$ fatty acids compared with the WM and LW pigs.

Total MUFA to SFA ratios of the MLLT differed $(P<0.001)$, with a higher MUFA/SFA ratio for the Mangalitsa pigs, compared with the SL pigs (Table 4). On the other hand, total PUFA to SFA ratios differed $(P<0.001)$, with a higher PUFA/SFA ratio for the SL pigs, compared with that of the Mangalitsa pigs. The fatty acid composition of the intramuscular fat is influenced by several factors, of which diet in general seems to be one of the most important (Nürnberg et al., 1998). Similarly, higher concentration of PUFA in organically produced pigs may not only be a result of the different feed, but may also be partially caused by a higher lean meat percentage (Hansen et al., 2006).

Holló et al. (2003) determined MUFA values in MLLT from Mangalitsa pigs as ranging between $56.0 \%$ and $56.1 \%$, PUFA values ranging between $6.51 \%$ and $8.24 \%$ and SFA values between $35.8 \%$ and $37.4 \%$. Loins of Iberian pork were characterized by a high concentration of MUFA in intramuscular fat of the $M L L T$, especially where animals were reared in an open system and fed grasses and acorns (59.2\%), while two other groups of animals, reared in a closed system, regardless of the diet provided, showed no difference in MUFA concentration (56.7\% and 56.3\%) (Daza et al., 2007).

The SL pigs showed a higher PUFA concentration in their MLLT than the Mangalitsa pigs. These differences were produced mainly by their higher total $n$-6 PUFA content $(P<0.001)$. However, SBM had a higher level of total $n$-3 PUFA $(P<0.001)$ than SL and WM pigs. These led to lower $(P<0.001) n-6 / n-3$ ratios in $M L L T$ of SBM pigs. Therefore, the $n-6 / n-3$ ratio was higher than dietary recommendations in all cases (British Nutrition Foundation, 1994). The housing system and diet of Mangalitsa pigs can significantly affect this ratio. For example, Parunović et al. (2012b) found that free-range Mangalitsa pigs showed a higher PUFA content in the MLLT than pigs reared indoors and fed conventionally. These differences were produced mainly by an almost four times higher total $n$-3 PUFA concentration in the MLLT of the free-range pigs $(P<0.001)$, and also by slightly higher $(P>0.05)$ levels of total $n$-6 PUFA. These led to lower $(P$ $<0.001) n-6 / n-3$ ratios in the $M L L T$ of the pigs reared outdoors and fed on acorns and free pasture.

In our study, the C18:3 $n-3$ concentration was higher $(P<0.001)$ in the MLLT of SBM than in that of WM and SL pigs. Other researchers found a higher total $n$-3 PUFA concentration in muscle phospholipids of animals fed a diet high in C18:3 n-3 (Ahn et al., 1996; Specht-Overholt et al., 1997), and increasing levels of C18:3 n-3, which were responsible mainly for a higher total $n$-3 PUFA. A diet with a higher C18:3n-3 content led to increased amounts of certain fatty acids of the $n-3$ pathway, especially eicosapentaenoic acid (EPA) (C20:5 $n$-3) and C22:5 $n$-3, although not docosahexaenoic acid (DHA) (C22:6 $n$-3). In the study by Muriel et al. (2002), all individual $n$-3 PUFA, including EPA, DHA and C22:5 $n$-3, were significantly higher in animals reared outdoors and fed on acorns and pasture than in indoor-bred animals that were fed concentrates. The role of EPA and DHA in easing the symptoms of a number of diseases, including coronary heart disease, has been acknowledged (British Nutrition Foundation, 1994). An increasing EPA and DHA content and a decreasing $n-6 / n-3$ ratio, together with high MUFA levels, indicate a potentially beneficial effect of feeding animals on pasture and support a 'healthy' image of 'organic' pork. In fact, nutritional studies have already related the inclusion of meat products from Iberian pigs reared outdoors in the diet of humans with improvement in plasmatic indicators of coronary and vascular disease (García et al., 1998). Positive features of feeding pigs with grass are levels of the nutritionally important long chain $n$ - 3 PUFA are the increased i.e. EPA (20:5 n-3) and DHA (22:6n-3) concentrations. Future research should focus on increasing, $n-3$ PUFA proportions in lean carcasses and the use of biodiverse pastures and conservation processes that retain the benefits of fresh leafy grass, and offer opportunities to achieve this. The varying fatty acid compositions of adipose tissue and muscle have profound effects on meat quality (Wood et al., 2008). 
As for the PUFA/SFA ratio, the $n-6 / n-3$ ratio of the total lipid fraction may vary depending on the $n-6 / n-3$ ratio of the phospholipid and triacylglycerol fractions, although the $n-6 / n-3$ ratios are much more affected by feeding than by genetics, as shown for example for pork (Enser et al., 2000) and for beef (Itoh et al., 1999; Choi et al., 2000) and as reviewed by Raes et al. (2004). The $n-6 / n-3$ ratio plays an important role in reducing the risk of coronary heart disease (American Heart Association, 2008). However, the optimal balance between these two classes of fatty acid is still a matter of debate (Simopoulos, 2002). The $n-6$ PUFAs are involved in the synthesis of eicosanoids biologically active in very small quantities and with properties that are much more inflammatory than eicosanoids from the $n$-3 PUFAs (Simopoulos, 2002). Therefore, nutritional guidelines recommend that fat intake, especially SFA, should be reduced and the intake of $n-6$ fatty acids minimized relative to $n-3$ fatty acids (UK Department of Health, 1994).

Modern pig breeds are more prone to stress than the Mangalitsa and similar unimproved breeds. Honkavaara (1989) and Piedrafita et al. (2001) found only minor effects of the stress susceptibility genotype on the subcutaneous and intramuscular fatty acid profile of pigs. Hartmann et al. (1997), however, found a significantly higher PUFA/SFA ratio in muscle and adipose tissue for stress-susceptible pigs compared with normal pigs, but the authors also reported highly significant inverse relationships between the PUFA/SFA ratio and total lipid content in various tissues. Our research has shown that the ratio of PUFA/SFA was significantly higher in SL pigs than in both strains of Mangalitsa pigs.

Genotype significantly affected total SFA content in MLLT $(P<0.001)$, with SL producing higher levels than Mangalitsa pigs. The average value of SFA (43.4\%) in SL pigs was higher than in WM and SBM pigs (Table 4$)$. These differences were produced mainly by higher $(P<0.001)$ stearic acid $(\mathrm{C} 18: 0)$ and $(P$ $<0.001)$ arachidic acid (C20:0) levels in their MLLT. Myristic acid (C14:0) and palmitic acid (C16:0) levels did not differ $(P>0.05)$ between the pig genotypes. The SBM and WM pigs had a higher $(P<0.01)$ C17:0 concentration than the SL pigs. However, stearic acid (C18:0) is considered a neutral fatty acid that has no effect on blood cholesterol (Mahan \& Escott-Stump, 2000), compared with myristic acid (C14:0) and palmitic acid (C16:0), which have strong influences.

In our research, the type of genotype had a significant effect $(P<0.001)$ on cholesterol content in the MLLT of the pigs. Cholesterol content in MLLT was the lowest in SL pigs. The total cholesterol concentration in MLLT of SBM and WM pigs ranged from a minimum of $52.5 \mathrm{mg} / 100 \mathrm{~g}$ to a maximum of $76.9 \mathrm{mg} / 100 \mathrm{~g}$, while the level of cholesterol concentration of SL pigs ranged from a minimum of 38.6 $\mathrm{mg} / 100 \mathrm{~g}$ to a maximum of $55.1 \mathrm{mg} / 100 \mathrm{~g}$. No statistically significant differences were established in the cholesterol content in SBM and WM. A number of previous studies reported lower levels of cholesterol in MLLT with $59 \mathrm{mg} / 100 \mathrm{~g}$ (Moss et al., 1983) and $57 \mathrm{mg} / 100 \mathrm{~g}$ (Dorado et al., 1999). Similarly, Bohac \& Rhee (1988) reported cholesterol content of $55.9 \mathrm{mg} / 100 \mathrm{~g}, 53.1 \mathrm{mg} / 100 \mathrm{~g}$, and $59.7 \mathrm{mg} / 100 \mathrm{~g}$ for MLLT. On the other hand, Tu et al. (1967) reported that the cholesterol contents were from $62 \mathrm{mg} / 100 \mathrm{~g}$ to $65 \mathrm{mg} / 100 \mathrm{~g}$ for pork MLLT. In a similar study, Parunović et al. (2012a) reported that the average cholesterol concentration in meat of WM was $63.3 \mathrm{mg}$, and varied from 52.0 to $76.9 \mathrm{mg} / 100 \mathrm{~g}$. The average cholesterol content in $100 \mathrm{~g}$ MLLT of WM fattener pigs was $14.8 \mathrm{mg}$ higher than in the meat of SL, and $1.15 \mathrm{mg}$ higher than in the meat of SBM (Parunović et al., 2012a). The average cholesterol content in SBM was $62.2 \mathrm{mg} / 100$ g, which was $13.63 \%$ higher than in SL. No statistically significant differences in cholesterol content were found between the two Mangalitsa genotypes in that study. These values correspond well with our current data. Measurements taken by Csapó et al. (2002) indicate that the cholesterol concentration of Mangalitsa pig fat varied between $71 \mathrm{mg} / 100 \mathrm{~g}$ and $109 \mathrm{mg} / 100 \mathrm{~g}$. The authors concluded that there is no truth in reports that indicate that the fat of the Mangalitsa pigs contains less cholesterol than that of the more generally produced types of fattening pig. Muchenje et al. (2009) and Mapiye et al. (2010) concluded that the cholesterol levels in beef were not affected by diet. The finding that diet had no substantial effects on meat cholesterol contradicts the results of García \& Casal (1992), who observed that beef from steers finished on pasture had lower fat and cholesterol concentrations than that from concentrate-fed ones.

\section{Conclusion}

The results of our research led us to note differences between pig genotypes, especially between their carcass properties, chemical and cholesterol content and fatty acids composition in the MLTT. A significantly higher percentage of water in muscle tissues of SL, and a higher percentage of total fat in both Mangalitsa genotypes confirmed breed characteristics of these pigs and values obtained in research by other authors. The SL had significantly less cholesterol in its MLTT compared with SBM and WM. However, differences in the 
content of saturated and unsaturated fatty acids were more expressed and distinct. A higher percentage of unsaturated fatty acids, which are purportedly less harmful to human health, were measured in WM and SBM breeds, whereas the percentage of saturated fatty acids was proven to be significantly higher in SL pigs.

\section{Acknowledgements}

This research was part of the project "Application of different breeding, selection and biotechnological methods for refinement of pigs", funded by Ministry of Science, Republic of Serbia, Record number 31081, project manager: Milica Petrovic. The authors would like to thank all participants in the project and in this paper.

\section{References}

Ahn, D.U., Lutz, S. \& Sim, J.S., 1996. Effects of dietary $\alpha$-linolenic acid on the fatty acid composition, storage stability and sensory characteristics of pork loin. Meat Sci. 43, 291-299.

Aldai, N., Murray, B.E., Nájera, A.I., Troy, D.J. \& Osoro, K., 2005. Review: Derivatization of fatty acids and its application for conjugated linoleic acid studies in ruminant meat lipids. J. Sci. Food Agr. 85, 1073-1083.

Alfaia, C.M.M., Castro, M.L.F., Martins, S.I.V., Portugal, A.P.V., Alves, S.P.A., Fontes, C.M.G.A., Bessa, R.J.B. \& Prates, J.A.M., 2007. Effect of slaughter season on fatty acid composition, conjugated linoleic acid isomers and nutritional value of intramuscular fat in Barrosã-PDO veal. Meat Sci. 75, 44-52.

American Heart Association, 2008. Heart and Stroke Encyclopedia. Dietary Guidelines for Healthy American Adults. Cholesterol. Fat. Retrieved September 13, 2008 from World Wide Web: http://www.americanheart.org.

Andrés, A.I., Cava, R., Mayoral, A.I., Tejeda, J.F., Morcuende, D. \& Ruiz, J., 2001. Oxidative stability and fatty acid composition of pig muscles as affected by rearing system, crossbreeding and metabolic type of muscle fiber. Meat Sci. 59, 39-47.

Anupam, K., Dipanwita, P., Gopal, P. \& Subhasish, B., 2010. Effect of slaughter weight on slaughter performance of a native swine breed “Ghungroo" of Duars' Valley and allied zone. Vet. World 3 (11), 509-511.

AOAC, 1990. Official methods of analysis of the Association of Official Analytical Chemists. $15^{\text {th }}$ ed. Washington, DC, USA.

Barton Gade, P.A. \& Blaabjerg, L.O., 1989. Preliminary observations on the behaviour and meat quality of free-range pigs. In: Proc. $35^{\text {th }}$ Int. Conf. Meat Science and Technology, Copenhagen. Denmark. pp. 1002-1005.

Bohac, C.E. \& Rhee, K.S., 1988. Influence of animal diet and muscle location on cholesterol content of beef and pork muscles. Meat Sci. 23, 71-75.

British Nutrition Foundation, 1994. Unsaturated fatty acids. Nutritional and physiological significance. Report of the British Nutrition TASk Force. London: British Nutrition Foundation.

Brouwer, I.A., Wanders, A.J. \& Katan, M.B., 2010. Effect of animal and industrial trans-fatty acids on HDL and LDL cholesterol levels in humans - a quantitative review. PLoS One 5 (3), 1-10.

Burlingame, B., Nishida, C., Uauy, R. \& Weisell, R., 2009. Fats and fatty acids in human nutrition: introduction. Ann. Nutr. Metabol. 55, 5-7.

Cameron, N.D., Warriss, P.D., Porter, S.J. \& Enser, M.B., 1990. Comparison of Duroc and British Landrace pigs for meat and eating quality. Meat Sci. 27, 227-247.

Cameron, N.D. \& Enser, M.B., 1991. Fatty-acid composition of lipid in longissimus dorsi muscle of Duroc and British landrace pigs and its relationship with eating quality. Meat Sci. 29, 295-307.

Cameron, N.D., Enser, M., Nute, G.R., Whittington, F.M., Penman, J.C., Fisken, A.C., Perry, A.M. \& Wood, J.D., 2000. Genotype with nutrition interaction on fatty acid composition of intramuscular fat and the relationship with flavor of pig meat. Meat Sci. 55, 87-195.

Choi, N.J., Enser, M., Wood, J.D. \& Scollan, N.D., 2000. Effect of breed on the deposition in beef muscle and adipose tissue of dietary n-3 polyunsaturated fatty acids. Anim Sci. 71, 509-519. 
Csapó, J., Húsvéth, F., Csapóné-Kiss, Z., Horn, P., Házas, Z., Vargáné-Visi, É. \& Bõcs, K., 1999. Fatty acid and cholesterol composition of the lard of different genotypes of swine. Acta Agraria Kaposvariensis, 3 (3), 1-13.

Csapó, J., Vargá-Visi, É., Csapó-Kiss, Z.S. \& Csokona, É., 2002. Fatty acid composition and cholesterol content of the fat of pigs of various genotypes. Acta Agraria Kaposvariensis 6 (2), 107-113.

Daza, A., Menoyo, D., Olivares, A., Cordero, G. \& López-Bote, C.J., 2007. Effect of Iberian pig feeding system on tissue fatty-acid composition and backfat rheological properties. J. Anim. Feed Sci. 16, 408-419.

Department of Health, 1994. Nutritional aspects of cardiovascular disease. Report on Health and Social Subjects No. 46, London.

De Smet, S., Raes, K. \& Demeyer, D., 2004. Meat fatty acid composition as affected by fatness and genetic factors: A review. Anim. Res. 53, 81-98.

Dorado, M., Martin Gomez, E.M., Jimenez-Colmenero, F. \& Masoud, T.A., 1999. Cholestrol and fat contents of spanish commercial pork cuts. Meat Sci. 51, 321-323.

Egerszegi, I., Ratky, J., Solti, L. \& Brussow, K.P., 2003. Mangalica - an indigenous swine breed from Hungary (Review). Arch Tierz Dummerstorf 46 (3), 245-256.

Ender, K., Nürnberg, K., Wegner, J. \& Seregi, J., 2002. Fleisch und Fett von Mangalitza-Schweinen im Labor. Fleischwirtschaft 6, 125-128.

Enfält, A.C., Lundström, K., Hansson, I., Lundeheim, H. \& Nyström, P.E., 1997. Effects of outdoor housing and sire breed (Duroc or Yorkshire) on carcass composition and sensory and technological meat quality. Meat Sci. 45, 1-15.

Enser, M., Richardson, R.I., Wood, J.D., Gill, B.P. \& Sheard, P.R., 2000. Feeding linseed to increase the n-3 PUFA of pork: Fatty acid composition of muscle, adipose tissue, liver and sausages. Meat Sci. 55, 201-212.

Estévez, M., Morcuende, D. \& Cava López, R., 2003. Physico-chemical characteristics of m. longissimus dorsi from three lines of free-range reared Iberian pigs slaughtered at $90 \mathrm{~kg}$ live-weight and commercial pigs: a comparative study. Meat Sci. 64, 499-506.

Flegler, J., 1999. Das Wollschwein. Gefährdete Nutztierrasse des Jahres 1999. Informationsbroschüre GEH.

Forman, D., 1999. Meat \& Cancer: a relation in search of mechanism. Lancet 353, 686-687.

García, P.T. \& Casal, J.J., 1992. Lipids in longissimus muscles from grass or grain fed steers. In Proc. 38th International Congress of Meat Science and Technology, Vol. 2, pp. 53-56.

García, A., Macia, E., Ortiz, A., Morales, J., Martín, M., Fallola, A., Mena, P. \& Campillo, J.E., 1998. Effects of consumption of meat product rich in monounsaturated fatty acids (the ham from the Iberian pig) on plasma lipids. Nutr. Res. 18, 743-750.

Griffin, B.A., 2008. How relevant is the ratio of dietary n-6 to n-3 polyunsaturated fatty acids to cardiovascular disease risk? Evidence from the OPTILIP study. Curr. Opin. Lipidol. 19, 57-62.

Grys, S., 1995. The role of gamma-linolenic acid in human organism. in: Mat. of II symp. ref. "Oil from evening primrose in prophylaxis and therapy”. 6-7 October, 1995., Łódź Poland, Makolab, 22-34.

Hansen, L.L., Claudi-Magnussen, C., Jensen, S.K. \& Andersen, H.J., 2006. Effect of organic pig production systems on performance and meat quality. Meat Sci. 74, 605-615.

Harris, W.S., Mozaffarian, D., Lefevre, M., Toner, C.D., Colombo, J., Cunnane, S.C., Holden, J.M., Klurfeld, D.M., Morris, M.C. \& Whelan, J., 2009. Towards establishing dietary reference intakes for eicosapentaenoic and docosahexaenoic acids. J. Nutr. 139, 804S-819S.

Hartmann, S., Otten, W., Kratzmair, M., Seewald, M.J., Iaizzo, P.A. \& Eichinger, H.M., 1997. Influences of breed, sex, and susceptibility to malignant hyperthermia on lipid composition of skeletal muscle and adipose tissue in swine. Am. J. Vet. Res. 58, 738-743.

Hoffman, L.C., Styger, E., Muller, M. \& Brand, T.S., 2003. The growth and carcass and meat characteristics of pigs raised in a free-range or conventional housing system. S. Afr. J. Anim. Sci. 33, 166-175.

Högberg, A., Pickova, J., Andersson, K. \& Lundström, K., 2003. Fatty acid composition and tocopherol content of muscle in pigs fed organic and conventional feed with different $n 6 / n 3$ ratios, respectively. Food Chem. 80, 177-186.

Holló, G., Seregi, J., Ender, K., Nürnberg, K., Wegner, J., Seenger, J., Holló, I. \& Repa, I., 2003. Examination of meat quality and fatty acid composition of Mangalitsa. Acta Agraria Kaposvariensis 7 (2), 19-32. 
Honkavaara, M., 1989. Einfluss der Stressempfindlichkeit und Rasse von Schweinen auf die Fettsaurenprofile der Subkutanen und intramuskularen Gesamtlipide (Influence of stress sensitivity and breed of pigs on the fatty acid profile of subcutaneous and intramuscular total lipids). Fleischwirtschaft 69, 1484-1488.

Itoh, M., Johnson, C.B., Cosgrove, G.P., Muir, P.D. \& Purchas, R.W., 1999. Intramuscular fatty acid composition of neutral and polar lipids for heavyweight Angus and Simmental steers finished on pasture or grain. J. Sci. Food Agr. 79, 821-827.

Jacyno, E., Pietruszka, A. \& Kołodziej, A., 2006. Influence of pig meatiness on pork meat quality. Pol. J. Food Nutr. Sci. 15/56 (2), 137-140.

Kim, J.H., Seong, P.N., Cho, S.H., Park, B.Y., Hah, K.H., Yu, L.H., Lim, D.G., Hwang, I.H., Kim, D.H., Lee, J.M. \& Ahn, C.N., 2008. Characterization of nutritional value for twenty-one pork muscles. Asian-Aust. J. Anim. Sci. 21, 138-143.

Mahan, L.K. \& Escott-Stump, S., 2000. Krause's food, nutrition and diet therapy. (10th ed.). Pennsylvania: W. B. Saunders Company.

Mapiye, C., Chimonyo, M., Dzama, K., Muchenje, V. \& Strydom, P.E., 2010. Meat quality attributes of Nguni steers supplemented with Acacia karroo leaf-meal. Meat Sci. 8, 621-627.

Mapiye, C., Chimonyo, M., Dzama, K., Hugo, A., Strydom, P.E. \& Muchenje, V., 2011. Fatty acid composition of beef from Nguni steers supplemented with Acacia karroo leaf-meal. J. Food Compos. Anal. 24 (4-5). 523-528.

Maraschiello, C., Diaz, I. \& Regueiro, J.A.G., 1996. Determination of cholesterol in fat and muscle of pig by HPLC and capillary gas chromatography with solvent venting injection. J. High Resolut. Chrom. 19, 165-168.

Moss, M., Holden, J.M., Ono, K., Cross, R., Slover, H., Berry, B., Lanza, E., Thompson, R., Wolf, W., Vanderslice, J., Johnson, H. \& Stewart, K., 1983. Nutrient composition of fresh retail pork. J. Food Sci. 48, 1767-1771.

Muchenje, V., Hugo, A., Dzama, K., Chimonyo, M., Raats, J.G. \& Strydom, P.E., 2009. Cholesterol levels and fatty acid profiles of meat from Nguni, Bonsmara and Angus steers raised on natural pasture. J. Food Compos. Anal. 22, 354-358.

Muriel, E., Ruiz, J., Ventanas, V. \& Antequera, T., 2002. Free-range rearing increases (n-3) polyunsaturated fatty acids of neutral and polar lipids in swine muscles. Food Chem. 78, 219-225.

Nilzén, V., Babol, J., Dutta, P.C., Lundeheim, N., Enfält, A.C. \& Lundström, K., 2001. Free range rearing of pigs with access to pasture grazing - effect on fatty acid composition and lipid oxidation products. Meat Sci. 58, 267-275.

Nürnberg, K., Wegner, J. \& Ender, K., 1998. Factors influencing fat composition in muscle and adipose tissue of farm animals. Livest. Prod. Sci. 56, 145-156.

Parunović, N., Petrović, M., Matekalo-Sverak, V., Radojković, D., Vranić, D. \& Radović, Č., 2012a. Cholesterol and total fatty acid content in $m$. longissimus dorsi of Mangalitsa and Swedish Landrace. Acta Alimentaria 41 (2), 161-171.

Parunović, N., Petrović, M., Matekalo-Sverak, V., Trbović, D., Mijatović, M. \& Radović, Č., 2012b. Fatty acid profile and cholesterol content of $m$. longissimus of free-range and conventionally reared Mangalitsa pigs. S. Afr. J. Anim. Sci. 42, 101-113.

Petrović, M., Mijatović, M., Radović, Č., Radojković, D., Parunović, N. \& Stanišić, N., 2009. Genetic resources in pig breeding - carcass and meat quality traits of moravka and mangalitsa breeds. $1^{\text {st }}$ Conference of the Balkan Network for the Animal Reproduction Biotechnology Institute of biology and immunology of reproduction "Acad. Kiril Bratanov". Genetic resources in pig breeding - carcass and meat quality traits of Moravka and Mangalitsa breeds. p. 14.

Petrović, M., Radović, Č., Parunović, N., Mijatović, M., Radojković, D., Aleksić, S., Stanišić, N. \& Popovac, M., 2010. Quality traits of carcass sides and meat of Moravka and Mangalitsa pig breeds. Biotechnol. Anim. Husb. 26 (1-2), 21-27.

Piedrafita, J., Christian, L.L. \& Lonergan, S.M., 2001. Fatty acid profiles in three stress genotypes of swine and relationships with performance, carcass and meat quality traits. Meat Sci. 57, 71-77.

Pugliese, C., Bozzi, R., Campodoni, G., Acciaioli, A., Franci, O. \& Gandini, G., 2005. Performance of Cinta Senese pigs reared outdoors and indoors: 1 . Meat and subcutaneous fat characteristics. Meat Sci. 69, 459-464. 
Raes, K., Haak, L., Balcaen, A., Claeys, E., Demeyer, D. \& De Smet, S., 2004. Effect of linseed feeding at similar linoleic acid levels on the fatty acid composition of double-muscled Belgian Blue young bulls. Meat Sci. 66, 307-315.

Rahelić, S., 1984. Uzgoj svinje i meso. (Swine breeding and meat) Zagreb: Školska knjiga.

Rey, A.I., López-Bote, C.J. \& Buckley, D.J., 2004. Effect of feed on cholesterol concentration and oxidation products development of longissimus dorsi muscle from Iberian pigs. Ir. J. Agr. Food Res. 43, 69-83.

Riediger, N.D., Othman, R.A., Suh, M. \& Moghadasian, M.H., 2009. A systemic review of the roles of n-3 fatty acids in health and disease. J. Am. Diet Assoc. 109, 668-679.

Rudel, L.L., Park, J.S. \& Sawyer, J.K., 1995. Compared with dietary monounsaturated and saturated fat, polyunsaturated fat protects African green monkeys from coronary artery atherosclerosis. Arterioscler. Thromb. Vasc. Biol. 15, 2101-2110.

Ruiz, J., Cava, R., Antequera, T., Martín, L., Ventanas, J. \& López-Bote, C.J., 1998. Prediction of the feeding background of Iberian pigs using the fatty acid profile of subcutaneous, muscle and hepatic fat. Meat Sci. 49, 155-165.

Sans, P., Andrade, M.J., Ventanas, S. \& Ruiz, J., 2004. Quality characteristics of fresh meat from pigs of the Gascon. Food Sci. Technol. Int. 10 (1), 29-34.

SAS 9.1.3, 2002-2003. SAS Institute Inc., Cary, NC, USA.

Sather, A.P., Jones, S.D.M., Schaefer, A.L., Colyn, J. \& Robertson, W.M., 1997. Feedlot performance, carcass composition and meat quality of free-range housed pigs. Can. J. Anim. Sci. 77, 225-232.

Simopoulos, A.P., 2002. The importance of the ratio of omega-6/omega-3 essential fatty acids. Biomed. Pharmacother 56, 365-379.

Simopoulos, A.P., 2004. Omega-6/omega-3 essential fatty acid ratio and chronic diseases. Food Rev. Int. 20, 77-90.

Specht-Overholt, S., Romans, J.R., Marchello, M.J., Izard, R.S., Crews, M.G., Simon, D.M., Costello, W.J. \& Evenson, P.D., 1997. Fatty acid composition of commercially manufactured omega - 3 enriched pork products, haddock and mackerel. J. Anim. Sci. 75, 2335-2343.

Spirić A., Trbovic D., Vranic D., Djinovic J., Petronijevic R. \& Matekalo-Sverak, V., 2010. Statistical evaluation of fatty acid profile and cholesterol content in fish (common carp) lipids obtained by different sample preparation procedures. Anal. Chim. Acta 672, 66-71.

SRPS EN ISO 5509:2007, 2007. Animal and vegetable fats and oils - Preparation of methyl esters of fatty acids.

Suzuki, K., Shibata, T., Kadowaki, H., Abe, H. \& Toyoshima, T., 2003. Meat quality comparison of Berkshire, Duroc and crossbred pigs sired by Berkshire and Duroc. Meat Sci. 64, 35-42.

Suzuki, K., Ishida, M., Kadowaki, H., Shibata, T., Uchida, H. \& Nishida, A., 2006. Genetic correlations among fatty acid compositions in different sites of fat tissues, meat production, and meat quality traits in Duroc pigs. J. Anim. Sci. 84, 2026-2034.

Szabó, P., 2001. Achievement in Mangalitza crossbreeding. SAVE-DAGENE International Meeting of Mangalica Breeders Budapest.

Szabó, P., 2002. Theriogenological results of alternative pig breeds. (Alternatív sertésfajták szaporodásbiológiai eredményei). Innováció, a tudomány és a gyakorlat egysége az ezredforduló agráriumában, Debrecen, 97-102.

Zăhan, M., Miclea, V., Hettig, A., Miclea, I., Raica, P. \& Roman, I., 2010. The use of molecular and biochemical markers in Mangalitsa breed characterization. Bulletin UASVM, Animal Science and Biotechnologies 67 (1-2), 452-455.

Zhang, S., Knight, T.J., Stalder, K.J., Goodwin, R.N., Lonergan, S.M. \& Beitz, D.C., 2007. Effects of breed, sex, and halothane genotype on fatty acid composition of pork longissimus muscle. J. Anim. Sci. 85, 583-591.

Tu, C., Powrie, W.D. \& Fennema, O., 1967. Free and sterified cholesterol content of animal muscles and meat products. J. Food Sci. 32, 30-34.

USDA and HHS, 2010. Dietary Guidelines for Americans 2010. Department of Health and Human Services (HHS)/Department of Agriculture (USDA) Available from http://www.cnpp.usda.gov/DGAs 2010DGACReport.htm. 
Yang, K.X., Ma, J.W., Guo, Y.M., Guo, T.F., Zhao, Y.G., Ding, N.S., Betti, M., Plastow, G.S. \& Huang, L.S., 2010. Correlations between fat depot traits and fatty acid composition in abdominal subcutaneous adipose tissue and longissimus muscle: Results from a White Duroc $\times$ Erhualian intercross F 2 population. J. Anim. Sci. 88, 3538-3545.

Wood, J.D., Enser, M., Fisher, A.V., Nute, G.R., Sheard, P.R., Richardson, R.I., Hughes, S.I. \& Whittington, F.N., 2008. Fat deposition, fatty acid composition and meat quality: a review. Meat Sci. 78, 343-358. 